\title{
Determinants Of Customer-Perceived Service Quality In Senior-Care Industry And Their Relationship To Customer Satisfaction And Behavioral Intentions: Research Findings From Taiwan
}

\author{
Hsing-Yun Chang, Northwestern Polytechnic University, USA \\ Cho-Pu Lin, Northwestern Polytechnic University, USA \\ Meng-Yun Tsou, Northwestern Polytechnic University, USA \\ Chien-Ting Chen, Fortune Institute of Technology College, Taiwan
}

\begin{abstract}
The senior-care market has been on the rise in Taiwan, especially in rural areas. Soaring competition among senior-care operators has led to escalating consumer demands on performances, driving the industry to become more customer-oriented. The authors examined the relationship between service quality of senior care and customer satisfaction in rural Taiwan based on Parasuraman, Zeithmal and Berry's SERVQUAL ten dimensions (i.e., access, communication, competence, courtesy, credibility, reliability, responsiveness, security, tangibles and understanding the customer) and Lee's food service. Multiple regression was conducted to test the relationships. The statistical results showed that access, courtesy and food service are significantly and positively related to customer satisfaction. This finding, among others, suggests that senior-care operators in rural Taiwan might have overlooked the above mentioned three dimensions as factors leading to customer satisfaction and, ultimately, to a sustainable competitive edge.
\end{abstract}

Keywords: Quality of Service, Customer Satisfaction, Consumer Behavior, Food Service, Senior Care.

\section{INTRODUCTION}

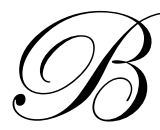

Jetween 2011, when the first baby boomers turn 65, and 2030, when the entire cohort reaches that age, the population of the seniors in Taiwan is projected to increase dramatically (Ministry of Interior Taiwan Department of Social Affairs, 2007). Due to rapid progress in health and technology, the life expectancy of Taiwan residents has extended. Council for Economic Development and Planning, a government agency affiliated to Administration Yuan, estimates that the old-age population in Taiwan will continue to increase until 2020 (Chiu, 2002). The seniors' growth rates in the past ten years, are shown in Table 1 (Ministry of Interior Taiwan Department of Social Affairs, 2007). As the older population becomes more diverse in ethnicity, dependence, health, economic status and education, services targeting older adults will need to be more flexible to meet their demands (Lee, 2002). There has been an apparent need for care, especially among the seniors living in rural Taiwan, where the young generations tend to leave their homes. According to Huang's (2004) observation, the senior-care market has been on the rise in Taiwan. Many outsiders have been attracted into this market for profits. Insurance companies and private entrepreneurs are highly enthusiastic about getting into this field (Chiu, 2006; Lee, 2003). Currently, the Senior Care Organizations (SCOs) have been one of the best choices available to the elderly living in rural Taiwan (Lee, 2007). 
The main purpose of the present study was to identify the focus of company marketing strategy at SCOs through assessing their customers' satisfaction with the service provided in rural areas of Taiwan. The SCOs, in order to achieve a sustainable competitive advantage, might need to invest more effort on certain priority dimensions of customer satisfaction. This advantage, in turn, will allow the SCOs to either maintain or advance their standings in the market. It is an advantage that enables a senior-care facility to survive against its competitors over a long period of time.

Table 1: Taiwan Residents Aged 65 and above ( Chiu, 2002)

\begin{tabular}{|c|c|c|}
\hline $\begin{array}{c}\text { Data source: Ministry of Interior Taiwan } \\
\text { Department of Social Affairs (8.9.2007) }\end{array}$ & Senior Population & \% of Total Population \\
\hline $\mathbf{1 9 9 8}$ & $1,810,231$ & 8.26 \\
\hline $\mathbf{1 9 9 9}$ & $1,865,472$ & 8.44 \\
\hline $\mathbf{2 0 0 0}$ & $1,921,308$ & 8.62 \\
\hline $\mathbf{2 0 0 1}$ & $1,973,357$ & 9.02 \\
\hline $\mathbf{2 0 0 2}$ & $2,031,300$ & 9.24 \\
\hline $\mathbf{2 0 0 3}$ & $2,087,734$ & 9.48 \\
\hline $\mathbf{2 0 0 4}$ & $2,150,475$ & 9.74 \\
\hline $\mathbf{2 0 0 5}$ & $2,216,804$ & 10.00 \\
\hline $\mathbf{2 0 0 6}$ & $2,287,029$ & 10.09 \\
\hline $\mathbf{2 0 0 7}$ (Jan-Jul) & $2,312,359$ & 14.00 \\
\hline $\mathbf{2 0 2 0}$ & & \\
\hline
\end{tabular}

\section{LITERATURE REVIEW}

A body of previous studies on this topic lends a solid basis to the present investigation. This literature includes: (1) SWOT analyses of the senior-care industry in Taiwan, (2) the condition of SCOs in rural areas of Taiwan, and (3) the relationship of service quality and customer satisfaction.

\subsection{SWOT Analyses Of Senior-Care Industry In Taiwan}

According to Ministry of Interior Taiwan Department of Social Affair (2007), Senior Welfare Organizations (SWOs) can be divided into five categories.

1. Long-Term Care Organizations: It is an entity that provides skilled nursing care and rehabilitation services to people with illnesses, injuries or functional disabilities, for example the nursing home. Services consist of: insert a tube, infuse a food, lead urine, and many other professional medical treatments.

2. Senior-Care Organizations: It is an entity that helps the seniors with activities of daily living, such as eating, bathing, dressing, laundry, housekeeping, and assistance with medications. Senior-care facilities are often deemed necessary when the person in question needs help preparing meals, bathing, dressing, performing household chores, is sometimes confused, or is experiencing memory problems. Many facilities also have centers for medical care; however, the care offered may not be as intensive or available to residents as the care offered at a nursing home. According to the Ministry of Interior Taiwan Department of Social Affair (2007) information shows that most SCOs are providing the combinative services, such as supported care, personal care, day care, and residential care.

3. Retirement Home Organizations: It is an entity that provides people who can take care of themselves and includes the adult living facilities, adult homes, sheltered housing, and retirement residences.

4. Senior Culture Organizations: Supporting the seniors' activities on entertainment, add-value, and communication.

5. Services Organizations: Providing the temporary day care, home care, long-term and short-term settle, law consulting services, job opportunity, etc. 
As of October 2007, Ministry of Interior Taiwan Department of Social Affair (2007) estimated the number of senior citizens in Taiwan at 3,085,275, which was about $10.2 \%$ of the total population. The same agency revealed that, as of October 2007, about 1,015 SWOs were providing long-term care to the seniors with a total capacity of around 62,000 beds, while only 46,000 seniors actually lived in those facilities. The occupancy rate was $74.19 \%$. On an extended time line, though, among the five types of SWOs, the occupancy rate in the SCOs reportedly increased from $1.04 \%$ in 1993 to $2.26 \%$ in 2005 (Ministry of Interior Taiwan Department of Statistic, 2008).

When developing marketing strategies for SCOs, the company has to set up a market compartment before establishing its market position; the company, then, can target its clients in the market. A SWOT analysis is the best way to help organizations to develop their advancing and retreating strategies (Skeese, 2002). Table 2 presents a layout of the strengths, weaknesses, opportunities and risk factors of the senior-care industry in Taiwan, as seen in scholarly works and governmental statistics.

Table 2: SWOT Analyses of the Senior-Care Industry in Taiwan

\begin{tabular}{|c|c|}
\hline Source & Strengths \\
\hline $\begin{array}{l}\text { Ministry of Interior Taiwan Department of } \\
\text { Social Affairs, } 2007\end{array}$ & $\begin{array}{l}765 \text { Senior Homes and SCOs existed in 2002, and the number jumped to } 983 \text { in } \\
2007 .\end{array}$ \\
\hline $\begin{array}{l}\text { Hung and Lee, 2004; Ministry of the Interior } \\
\text { of Taiwan Department of Social Affairs, } 2007\end{array}$ & $\begin{array}{l}\text { Because of increasing demands for SCOs and other senior services, the } \\
\text { government has started treating the related issues more seriously. }\end{array}$ \\
\hline Chen, 2002; Hsieh, 1993 & $\begin{array}{l}\text { Living in SCOs, the elderly can help ease family burdens while receiving } \\
\text { professional care. }\end{array}$ \\
\hline $\begin{array}{l}\text { Ministry of Interior Taiwan Department of } \\
\text { Statistics, 1998; Tsai, 2004 }\end{array}$ & $\begin{array}{l}\text { The massive migration of young people to the cities has left an aging } \\
\text { countryside in dire needs of professional care. }\end{array}$ \\
\hline Liao, 2007; Hsieh, 1993 & $\begin{array}{l}\text { Due to a social-structure change, the seniors are now more receptive to living in } \\
\text { public facilities, thereby creating potentials for SWOs. }\end{array}$ \\
\hline d Lee, 2004 & $\begin{array}{l}\text { To meet senior-care needs and to ensure fairness in resource distribution, } \\
\text { governments of many counties have proposed specialized appraisal standards } \\
\text { with which to determine the appropriation of funds. }\end{array}$ \\
\hline Liao, 2007; Shi, 1994 & $\begin{array}{l}\text { Because of the lingering traditional concept of "raising the children to protect } \\
\text { against aging," many seniors in Taiwan are still partial to living together with } \\
\text { their offsprings. }\end{array}$ \\
\hline Tsai, 2004; Kong, 2004 & $\begin{array}{l}\text { Most scholars believe that there is an "urban bias" in Taiwan as most resources } \\
\text { are available only in the big cities. }\end{array}$ \\
\hline $\begin{array}{l}\text { Department of Health, 2002; Lee, 2004; } \\
\text { Chen, 2005; Kuo, } 2003\end{array}$ & $\begin{array}{l}\text { Several researches are targeting SWOs that have not registered with the } \\
\text { government. Their studies indicate that at least 7,500 seniors are now living in } \\
\text { those non-registered facilities, which usually offer low-quality services. }\end{array}$ \\
\hline Hsieh, 1993; Kuo, 2003; Tsai, 2005 & $\begin{array}{l}\text { As organizations emphasize operational efficiency at the cost of service quality, } \\
\text { staffs often provide unprofessional care or even maltreat senior customers. }\end{array}$ \\
\hline Chen, 2005; Kuo, 2003; Lee, 1997 & $\begin{array}{l}\text { Lacking professional care ethic and in order to increase the manpower and } \\
\text { reduce personnel costs, some organizations employ foreign workers, leading to } \\
\text { communication problems and poor service quality. }\end{array}$ \\
\hline Chen, 2005; Yang, Wang, and Chiang, 2005 & $\begin{array}{l}\text { Intense competition has made it difficult for organizations to innovate their } \\
\text { services. }\end{array}$ \\
\hline Chen, 2005; Lee, 2004 & $\begin{array}{l}\text { Many investors joining the senior-care market today are ill-prepared and often } \\
\text { focus on profits at the expense of quality and commitment. }\end{array}$ \\
\hline
\end{tabular}




\begin{tabular}{|c|c|c|}
\hline \multicolumn{3}{|c|}{ Threats and Opportunities (Chang, 2004) } \\
\hline Condition & Threats & Opportunities \\
\hline $\begin{array}{l}\text { Increase of elderly } \\
\text { population }\end{array}$ & $\begin{array}{l}\text { With increasing elderly annuity, personal } \\
\text { capitals have decreased. }\end{array}$ & $\begin{array}{l}\text { Recreational products and related services have } \\
\text { increased, so has the demand for smaller and more } \\
\text { comfortable homes. }\end{array}$ \\
\hline $\begin{array}{l}\text { Emergence of multiple } \\
\text { generations of seniors }\end{array}$ & $\begin{array}{l}\text { With slow economic growth, there has been } \\
\text { an increasing elderly dependence on } \\
\text { societal resources and loss of balance } \\
\text { between supply and demand. }\end{array}$ & $\begin{array}{l}\text { As greater variety is needed for new products and } \\
\text { services, there is still room for economic growth. }\end{array}$ \\
\hline Seniors being autocratic & $\begin{array}{l}\text { The decision-making power is on the } \\
\text { seniors' hands, leading to generation } \\
\text { conflict. }\end{array}$ & $\begin{array}{l}\text { There are needs for recreational products and training } \\
\text { programs. }\end{array}$ \\
\hline $\begin{array}{l}\text { Baby Boomer High } \\
\text { income }\end{array}$ & Value clash among generations & $\begin{array}{l}\text { As consumer spending increases, people demand } \\
\text { quality life, thus creating room for investment and, } \\
\text { ultimately, economic growth. }\end{array}$ \\
\hline $\begin{array}{l}\text { The population being } \\
\text { increasingly more } \\
\text { health-conscious } \\
\end{array}$ & Changing needs for health-care products & $\begin{array}{l}\text { While the pressure for elder annuity decreases, the } \\
\text { demand for senior-care products is increasing. }\end{array}$ \\
\hline Health-Conditions & $\begin{array}{l}\text { Increase of social resources pressure on } \\
\text { medical or manpower }\end{array}$ & $\begin{array}{l}\text { Demands for senior-care products/services are } \\
\text { increasing. }\end{array}$ \\
\hline $\begin{array}{l}\text { The Physiology Ability } \\
\text { Declines }\end{array}$ & Growing demands for assistance resources & $\begin{array}{l}\text { Both user-friendly products and senior-care services } \\
\text { are increasing. }\end{array}$ \\
\hline Technology & $\begin{array}{l}\text { Emergence of gap between the rich and } \\
\text { poor in owning high-tech services or } \\
\text { products }\end{array}$ & $\begin{array}{l}\text { Room for solving the problem and increasing service } \\
\text { efficiency }\end{array}$ \\
\hline Societal Resources & $\begin{array}{l}\text { Seniors are immigrating to foreign countries } \\
\text { due to a lack of local professional care. }\end{array}$ & $\begin{array}{l}\text { Growing demands for senior-care services, along with } \\
\text { increasing needs for safe products and environment }\end{array}$ \\
\hline
\end{tabular}

The SWOT Analysis shows that the current demand of the SCOs holds potential business in Taiwan both presently and in the future. Apparently, the SCOs will have to gird their loins for an intense senior-care business war.

\subsection{Senior-Care Organizations In Rural Taiwan}

According to several scholars' studies (i.e., Tsai, 1996; Chuang, 2000), the 18 counties are the rural areas in Taiwan, including villages and towns. Tsai (2004) mentions that most scholars believe there exists an "urban bias" in Taiwan. Lipton (2005) explains, "Urban Bias Thesis (UBT) proposes that urban classes in poorer countries use their social power to bias (distort) a range of public policies against members of the rural classes." Lipton maintains that this bias involves (a) an allocation to persons or organizations located in towns or (b) a disposition among the powerful urban classes to allocate resources in this way. Urban bias, so defined, is currently being witnessed in Taiwan's senior-care industry. The latest investigation indicates that the number of SCOs in Taiwan stands at 948 (Minister of Interior Taiwan Department of Social Affairs, 2007). SCOs are mostly established in big cities of Taiwan. For example, there are about 172 SCOs in Taipei County and 190 in Taipei City (Minister of Interior Taiwan Department of Social Affairs, 2007). Options are relatively limited for the rural seniors. More and more seniors living in rural areas, however, are asking for a greater supply of senior-care facilities (Tsai, 2004).

Moreover, SWOs' statistics (Minister of Interior Taiwan Department of Social Affairs, 2007) show that the supply is falling short of the demand in rural Taiwan. Take Taichung County as an example, while about 3,562 people have requested SWOs, the available facilities could accommodate only 1,945 people. The authors of the present study conducted an interview with H. Chang, Dean of the E.L.F.C.T. Senior Care Organizations in Tungshih 
Township, Taichung County, who said that this problem of short supply is clearly felt in his nonprofit SCO (Personal communication, October 4, 2007). This shortage, on the other hand, suggests business potential in rural Taiwan.

\subsection{Service Quality And Customer Satisfaction}

Several studies have shown that a high level of customer service quality can exert a positive influence on customer satisfaction (Cronin and Taylor, 1992; Zeithaml et al., 1996; Ramsaran-Fowdar, 2006). The relationship between service quality and customer satisfaction has been discussion during the past decade. According to Jun et al. (2004), some authors (e.g., Grönroos, 1983) argued that there is a significant overlap between these two concepts, and thus, they can be used interchangeably. Other researchers (e.g., Bitner et al., 1990; Carman, 1990; De Ruyter et al., 1997; Lee and Yoo, 2000), though, have attempted to differentiate between these two constructs. They argued that whereas service quality is an overall evaluation of the service under consideration, customer satisfaction is often viewed as the result of specific service transactions.

The authors of the present study used the theories by Parasuraman et al. (1985) and Lee (2002), who developed a general list of ten service quality dimensions (i.e., access, communication, competence, courtesy, credibility, reliability, responsiveness, security, tangibles, and understanding the customer) and food service dimension on measuring the customer satisfaction (see Table 3). Lee (2002) explains that food is an important contributor to the quality for life of older adults because of its social, psychological, and nutritional effects. By providing good food nutrition and social interaction opportunities, food service ultimately improves the quality of life for residents who live in SCOs. Concluding from Lee's studying (2002) the outcomes of food service (food) with the customer demand on healthy food, temperature of food, the menu provides choices, variety of foods are offered, tasty and quality of food, food services meets the customer's special request are important services to satisfy the senior residents in SCOs.

Table 3: Parasuraman et al's ten dimensions and Lee's Food Service (Source: Parasuraman et al., 1985, p. 6-7; Lee, 2002)

\begin{tabular}{|l|l|}
\hline Access & Ease of contacting service firm by telephone \\
\hline Communication & Explaining service to customers in language they can understand \\
\hline Courtesy & Knowledge and skill of customer-contact personnel \\
\hline Credibility & Friendliness of customer-contact personnel \\
\hline Reliability & Trustworthiness of customer-contact personnel \\
\hline Responsiveness & Performing dependable service \\
\hline Security & Willingness and ability to provide prompt service \\
\hline Tangibles & Confidentiality of transactions \\
\hline Understanding the Customers & Appearance of physical facilities and personnel \\
\hline Food Service & Effort to ascertain a customer's specific requirements \\
\hline
\end{tabular}

\section{RESEARCH DESIGN}

Based on the above-mentioned research findings, a quantitative analysis using survey and statistical methods was conducted to identify possible answers to the research question (listed below).

\subsection{Instrument Development}

The survey instrument was based on the combined designs by Lee (2002) food service and Nwankwo (2007) drawing on Parasuraman et al's (1985) ten service quality dimensions. The authors developed a questionnaire that asked the sample to evaluate SCOs' service quality as well as their customer satisfaction in rural areas of Taiwan. 
The questionnaire consisted of 26 Likert's 7-point scale items. Nearly half of the items are phrased positively, and half negatively. A positively worded statement is one for which a very satisfied participant would select "Strongly Agree." A negatively worded statement is one for which a very satisfied participant would check "Strongly Disagree". (Stamps, 1997).

\subsection{Population And Samples}

The authors hired Focus Survey Research Company to conduct the questionnaire survey and collect the data. The target population was the 19,815 seniors living in 580 private SCOs in rural areas of Taiwan, where a random sample was selected to participate in the survey through drop-off and face-to-face interviews. In order to obtain a reliable output, substantial consideration had to be given to the sample size (n) and the number of predictors (K). A recommended ratio is identified by Tabachnick and Fidell (1996), who put the simple rule of thumb as $\mathrm{n} \geqq 50+8 \mathrm{~K}$. Therefore, the sample size is $146(\mathrm{~K}=12$; including $11 \mathrm{IVs}$ and $1 \mathrm{DV})$ for the present study.

\subsection{Research Question And Hypothesis}

Research Question: Is there a significant relationship between the senior customers' satisfaction with the 11 dimensions of SCOs' service (i.e., access, communication, competence, courtesy, credibility, reliability, responsiveness, security, tangibles, understanding the customers, and food service) in rural areas of Taiwan?

Hypothesis: The senior customer satisfaction is highly correlated with the 11 dimensions in rural areas of Taiwan's senior-care industry.

Dependant Variable: Customer Satisfaction.

Independent Valuables: Eleven Dimensions (i.e., access, communication, competence, courtesy, credibility, reliability, responsiveness, security, tangibles, understanding the customers, and food service)

Statistical Method: Multiple Regression (Mertler and Vannatta, 2005).

\section{RESULTS AND DISCUSSION}

\subsection{Responses To The Survey}

In the present study, data were gathered during the period of May to June 2008 from a total of 392 SCOs respondents in rural Taiwan by the Focus Research Company. Data collection for the present study was commissioned to a professional survey company, Focus Research Company, which operated under the authors' directions. Each participant was provided (a) letter of introduction, (b) an informed consent form, and (c) a survey questionnaire. A total of 452 surveys were returned. On the basis of the data set obtained during the initial collection phase, some modifications on the questionnaire design were made to reduce the response time and, thus, to increase the response rate. 392 out of the 452 people had responded to the inquiry, with the response rate being around $86.73 \%$.

\subsection{Pre-Analysis Data Screening}

An evaluation of missing data and outliers (i.e., extreme values) led to the elimination of 91 cases, reducing the number of responses to 301 for further statistical analyses. The test of data normality, linearity, and homoscedasticity were also conducted in order to satisfy the general assumptions in multivariate statistical testing. Mertler and Vannatta (2005) suggested that "when the assumptions of linearity, normality, and homoscedasticity are met, residuals will create an approximate rectangular distribution with a concentration of scores along the center" (p.55). The scatterplots revealed that the residual plot created a rectangle shape with scores concentrated in the 
center, suggesting that the collected data set had satisfied the general assumptions of normality, linearity, and homoscedasticity in multivariate statistical testing.

\subsection{Statistical Results And Discussions}

Tables 4, 5 and 6 present three primary outputs of multiple regression. A review of the tolerance statistics presented in Table 6 indicated that all IVs were tolerated in the model (with the tolerance statistics exceeding 0.1). Mertler and Vannata (2005) state, "...if the tolerance value for a given IV is less than 0.1 , multicollinearity is a distinct problem" (p. 169). Thus, collinearity is not a serious problem for the current data. The model summary (see Table 4) and the ANOVA table (Table 5) indicate that the overall model of the 11 IVs is significantly related to the customer satisfaction [Adjusted $\left.\mathrm{R}^{2}=.553, \mathrm{~F}(11,289)=34.807, \mathrm{p}<.005\right]$. Therefore, the results supported the hypothesis that the 11 dimensions are significantly correlated with the senior customer satisfaction in the SCOs. In addition, the statistical results also showed that access, courtesy, and food service are particularly significantly and positively related to customer satisfaction. Although competence is a little higher than 0.05 , it is still close to being significant and positively related to customer satisfaction. Competence cannot be neglected. The statistical results here led to the development of a multiple regression function using beta weight (see Table 6).

Table 4: Model Summary

\begin{tabular}{|c|c|c|c|c|c|c|c|c|c|}
\hline Model & $\mathbf{R}$ & R Square & $\begin{array}{c}\text { Adjusted } \\
\text { R Square }\end{array}$ & $\begin{array}{c}\text { Std. Error of the } \\
\text { Estimate }\end{array}$ & \multicolumn{5}{|c|}{ Change Statistics } \\
\hline & & & & $\begin{array}{c}\text { R Square } \\
\text { Change }\end{array}$ & F Change & Df1 & Df2 & $\begin{array}{c}\text { Sig. F } \\
\text { Change }\end{array}$ \\
\hline 1 & $.755(\mathrm{a})$ & .570 & .553 & .54203 & .570 & 34.807 & 11 & 289 & .000 \\
\hline
\end{tabular}

Table 5: ANOVA

\begin{tabular}{|c|c|c|c|c|c|c|}
\hline Model & & Sum of Squares & df & Mean Square & F & Sig. \\
\hline 1 & Regression & 112.488 & 11 & 10.226 & 34.807 & $.000(\mathrm{a})$ \\
\hline & Residual & 84.907 & 289 & .294 & & \\
\hline & Total & 197.395 & 300 & & & \\
\hline
\end{tabular}

Table 6: Coefficients

\begin{tabular}{|l|l|c|c|c|c|c|c|c|c|c|c|}
\hline \multicolumn{2}{|c|}{ Model } & $\begin{array}{c}\text { Unstandardized } \\
\text { Coefficients }\end{array}$ & $\begin{array}{c}\text { Standardized } \\
\text { Coefficients }\end{array}$ & $\mathbf{t}$ & Sig. & \multicolumn{3}{|c|}{ Correlations } & \multicolumn{2}{c|}{$\begin{array}{c}\text { Collinearity } \\
\text { Statistics }\end{array}$} \\
\hline & $\mathbf{B}$ & $\begin{array}{c}\text { Std. } \\
\text { Error }\end{array}$ & $\mathbf{B e t a}$ & & & $\begin{array}{c}\text { Zero- } \\
\text { order }\end{array}$ & Partial & Part & Tolerance & VIF \\
\hline 1 & (Constant) & -.592 & .409 & & -1.449 & .148 & & & & & \\
\hline & Access & $\mathbf{. 1 9 4}$ & $\mathbf{. 0 8 1}$ & $\mathbf{. 1 5 7}$ & $\mathbf{2 . 3 8 8}$ & $\mathbf{. 0 1 8}$ & .610 & .139 & .092 & .344 & 2.911 \\
\hline & Communication & .029 & .069 & .028 & .418 & .677 & .559 & .025 & .016 & .338 & 2.958 \\
\hline & Competence & $\mathbf{. 1 2 6}$ & $\mathbf{. 0 7 3}$ & $\mathbf{. 0 9 8}$ & $\mathbf{1 . 7 2 9}$ & $\mathbf{. 0 8 5}$ & .557 & .101 & .067 & .467 & 2.142 \\
\hline & Courtesy & $\mathbf{. 2 3 9}$ & $\mathbf{. 0 8 5}$ & $\mathbf{. 1 8 2}$ & $\mathbf{2 . 8 2 3}$ & $\mathbf{. 0 0 5}$ & .618 & .164 & .109 & .357 & 2.801 \\
\hline & Credibility & .093 & .083 & .078 & 1.127 & .260 & .612 & .066 & .043 & .309 & 3.239 \\
\hline & Reliability & .064 & .089 & .051 & .711 & .478 & .608 & .042 & .027 & .292 & 3.426 \\
\hline & Responsiveness & .003 & .070 & .003 & .043 & .966 & .593 & .003 & .002 & .295 & 3.385 \\
\hline & Security & .051 & .076 & .036 & .676 & .500 & .464 & .040 & .026 & .534 & 1.874 \\
\hline & Tangibles & .050 & .069 & .041 & .716 & .474 & .523 & .042 & .028 & .450 & 2.224 \\
\hline & $\begin{array}{l}\text { Understanding } \\
\text { the customer }\end{array}$ & -.040 & .071 & -.036 & -.565 & .573 & .524 & -.033 & -.022 & .371 & 2.698 \\
\hline & Food Service & $\mathbf{. 3 2 6}$ & $\mathbf{. 0 5 2}$ & $\mathbf{. 3 0 9}$ & $\mathbf{6 . 2 3 2}$ & $\mathbf{. 0 0 0}$ & .619 & .344 & .240 & .604 & 1.657 \\
\hline
\end{tabular}

The general model for the hypothesis of the present study:

$\mathrm{Y}($ Customer Satisfaction $)=0.157 \mathrm{X}($ Access $)+0.028 \mathrm{X}($ Communication $)+0.098 \mathrm{X}($ Competence $)+0.182 \mathrm{X}($ Courtesy $)+0.078 \mathrm{X}$ $($ Credibility) $+0.051 X$ (Reliability) + 0.003X (Responsiveness) + 0.036X (Security) + 0.041X (Tangibles) - 0.036X (Understanding the Customer) $+0.309 \mathrm{X}$ (Food Service) . 


\section{CONCLUSION AND RECOMMENDATIONS}

Competition in the SCOs for senior people has been upheld as a means of increasing efficiency, driving down prices and raising the quality. Choices are made available to meet user expectations of health care and to improve service provision. Optimizing the management and process of care transitions of senior people is important to senior-care providers.

\subsection{Discovering Customer Needs}

As more baby boomers approach their retirement in Taiwan, the demand for a higher quality of senior-care services has increased. To pinpoint what the customers really need, SCOs in Taiwan should keep communicating with their customers to identify the priority dimensions towards customer satisfaction. For example, facility policies and staff training that maximize resident participation in daily decision-making should be encouraged.

\subsection{Reducing The Complexity And Fragmentation Of The Care Process System}

For senior service providers, it is important to reduce the complexity and fragmentation often observed of the care process system (Clarfield et al., 2001). It seems essential to encourage the SCOs either to provide a range of services across the care continuum or to develop partnerships with other providers whose services complement their own (Coleman et al., 2004; Cheek et al., 2006). This strategy could also limit the number of agencies a senior resident customer has to deal with, thereby reducing the complexity of the care system.

On the other hand, information technology available through the online comprehensive service may also be the best strategy to reduce the system complexity of the SCOs. Survey results by Vuori and Holmlund-Rytkonen (2005) revealed that people older than 50 are the second fastest-growing group on the Internet, trailing only to the 16 to 24 year-olds. A recent survey of people 55 years and older at Dell Corporation found that over $75 \%$ of respondents would be likely to purchase a personal computer if they knew they had someone to help them use it (Mahoney, 1999). The Internet service is quickly becoming an ideal method to present information to an aging audience (Angel, 1999). It could improve service coordination while enhancing stakeholders' knowledge and understanding of available services.

\subsection{Educating The Employees}

Other regulatory and policy constraints, such as requirements for employees training, will also pose a block to future competition among senior-care providers (Knibb, 2006). Therefore, providing quality services to the seniors is a multidimensional activity; employees' qualities are the key to customer satisfaction of the service quality (Cheek et al., 2006). If SCOs did not expend money, training their employees on new and improved methods of carrying out business would simply lag behind. Companies that have an employee performance management system have developed an affordable way to keep staffs trained and educated on the best possible methods. In order to accomplish long-term service quality performance, Cheek (2004) suggests that senior health care-related employee training should focus first on short-term programs that aim to improve the employee service performance in the long run. For the SCOs in rural Taiwan, education and training should emphasize access, competence, courtesy, food service, and how these factors may be employed to enhance the senior customer satisfaction.

\section{SCHOLARLY CONTRIBUTIONS}

The SCO managers often become so caught up in daily administration that they fail to recognize that the satisfaction of the ultimate customers goes unmeasured, and in many instances, is totally ignored. The present study is a pioneer in conducting empirical studies to develop a diagnostic instrument for senior customer satisfaction. This instrument may be an effective tool of evaluating ultimate customer satisfaction in the way of developing future employee training programs. The results of the present study suggest that the SCOs in the rural areas of Taiwan 
should customize their employee training programs to focus on friendly services, knowledgeable personnel with positive attitudes, and quality of food service. On the other hand, the findings suggest that the SCOs service providers might have overlooked the above-mentioned three priority dimensions of customer satisfaction which may have helped them gain a sustainable competitive advantage in rural Taiwan.

\section{LIMITATIONS}

Some of the surveyed senior residents in SCOs were not in good health, and their responses could have been biased or misleading. In addition, the administrators at the surveyed SCOs sometimes interrupted the survey process and therefore may have lowered the accuracy of data. Furthermore, as the study sample was taken from all of Taiwan, the results of the present study may not be generalized to specific or other regions of Taiwan. One other limitation of the study is the lack of data on the senior residents' family members who might have a significant impact upon the senior customers' satisfaction. Future studies may need to find out about these family members' views and satisfaction. Several researchers have found general satisfaction among the seniors and their families with the use of supports and services (Cheek et al., 2006; Buelow and Fee, 2000; Gregory, Gesell and Widmer, 2007). Pairing the seniors' and their family members' responses may be an interesting and useful approach to understanding the essence of senior customer satisfaction.

\section{AUTHOR INFORMATION}

H. Y. Chang holds a M.S in Marketing and M.B.A in Management from Golden Gate University, CA in 2005. She is now pursuing her DBA degree and currently a Teaching Assistant at the business school in Northwestern Polytechnic University, Fremont, CA. Her current research interest includes senior care market and related company strategic management.

C. P. Lin received his master degree in business administration from Northwestern Polytechnic University, Fremont, CA in 2006. He is now pursuing his DBA degree and is currently a Teaching Assistant at the business school in Northwestern Polytechnic University, Fremont, CA. His current research interest includes customer relationship management and related information technology.

M.Y. Tsou was awarded the degree of Master Business Administration from the University of Dubuque, Iowa in 2006. She is now pursuing her DBA degree at the business school in Northwestern Polytechnic University, Fremont, CA. Her current research topic focuses on customer relationship management.

C. T. Chen is currently faculty at the Department of Information Management, Fortune Institute of Technology, Kaohsiung, Taiwan, R.O.C. His current research interest focuses on customer relationship management.

\section{ACKNOWLEDGEMENTS}

We are grateful for the academic resources provided by Northwestern Polytechnic University, Fremont, CA, and Fortune Institute of Technology, Kaohsiung Country, Taiwan, Republic of China.

\section{REFERENCES}

1. Angel, J. I. (1999), "Helping Families to Navigate the System of Long-Term Care Alternatives: The Role of Information Technology," Journal of Family and Consumer Sciences, 91(3), p. 116.

2. Bitner, M. J., B. H. Booms, and M. S. Tetreault (1990), "The Service Encounter: Diagnosing Favorable and Unfavorable," Journal of Marketing, 54, pp. 71-84.

3. Buelow, J. R. and F. A. Fee (2000), "Perceptions of Care and Satisfaction in Assisted Living Facilities," Health Marketing Quarterly, 17(3), pp. 13-25. 
4. Carman, J. M. (1990), "Consumer Perceptions of Service Quality: An Assessment of the SERVQUAL Dimensions," Journal of Retailing, 66(1), pp. 33-35.

5. Chang, T. I. (2004), "Opportunities and Threats of the Senior Population Increasing," MD News, 61, pp. 21-27.

6. Cheek, J., A. Ballantyne, D. Gillham, and J. Mussared (2006), "Improving Care Transitions of Older People: Challenges for Today and Tomorrow," Quality in Ageing, 7(4), p. 18.

7. Cheek, J. (2004), “Older People and Acute Care: a Matter of Place?" Illness, Crisis and Loss, 2(1), pp. 52-62.

8. Chen, M. J. (2002), "The Adaptation Process of the Elderly in Long-Term Care Facilities," Education Department Dissertation Database (System No. 090NCNU0210004), 2002.

9. Chen, Z. P., "A Study of Kano Two-Dimensional Model on Social Welfare Quality in Chunghua County and Residents' Perceptions on the Importance of Service Quality," Unpublished Master's thesis, Dayeh University, Changhua, Taiwan, Republic of China, 2005.

10. Chiu, H. N., "The Influencing Factors to Retirement Home Decision in Taiwan," Unpublished Master's thesis, National Sun Yat-sen University, Kaohsiung, Taiwan, Republic of China, 2002.

11. Chiu, I. H., "The Senior Care Business Strategic Management," Unpublished Master's thesis, National Taipei University, Taipei, Taiwan, Republic of China, 2006.

12. Chuang, S. T. (2000). "A study the types of rural areas in Taiwan. Unpublished Doctoral Dissertation, National Taiwan University," Taipei, Taiwan, Republic of China.

13. Clarfield A. M., H. Bergman and R. Kane (2001), "Fragmentation of Care for Frail Older People - An International Problem. Experience form Three Countries: Israel, Canada, and the United States," Journal of the American Geriatrics Society, 49, pp. 1714-1721.

14. Coleman, E. A., J. D. Smith, J. C. Frank, S. Min, C. Parry and A. M. Kramer (2004), "Preparing Patients and Caregivers to Participate in Care Delivered Across Settings: The Care Transitions Intervention," Journal of the American Geriatrics Society, 52, pp. 1817-1825.

15. Cronin, J. J. and S. A. Taylor (1992), "Measuring Service Quality: A Reexamination and Extension," Journal of Marketing, 56, pp. 55-68.

16. Department of Health, Executive Yuan, Taiwan (2002), "Senior Care Development," Retrieved, October 16, 2002, from

http://www.doh.gov.tw/CHT2006/DM/SEARCH_MAIN.aspx?keyword=\%u8b77\%u7406\%u4e4b\% u5bb6.

17. De Ruyter, K., J. Bloemer and P. Peters (1997), "Merging Service Quality and Service Satisfaction: An Empirical Test of An Integrative Model," Journal of Economic Psychology and Marketing, 18(4), pp. 387-406.

18. Gregory, N., S. B. Gesell and T. Widmer (2007), "Improving Assisted Living Care,” Journal of Nursing Care Quality, 22(1), pp. 50-58.

19. Gronroos, C. (1983). "Strategic Management and Marketing in the Service Sector". Cambridge, MA: Marketing Science Institution.

20. Hsieh, M. H. (1993)，老人長期照護的相關議題 [“A Study of Senior Long-Term Care”] Taiwan, Republic of China: Laureate.

21. Huang, F. F. and H. L. Lee (2004), "Senior Care Service Result and Observation in Kaohsiung City," Community Development Journal, 106, pp. 38-45.

22. Huang, J. H. "Nonprofit Senior Care Organizations Operations Study," Unpublished Master's thesis, Tunghai University, Taichung, Taiwan, Republic of China, 2004.

23. Jun, M., Z. Yang and D. Kim (2004), "Customers' Perceptions of Online Retailing Service Quality and Their Satisfaction," The International Journal of Quality and Reliability Management, 21, pp. 817-840.

24. Knibb, W. (2006), "Competition and Choice in the Care Home Sector for Older People: A Case Study of the Market in Surrey," Quality in Ageing, 7(4), pp. 3-8.

25. Kong, W. H. (2004), "The Factors Influence the Seniors to choose a Continuing Care Retirement Community," Education Department Dissertation Database (System No. 092CGU00121020), 2004.

26. Kuo, L. W. (2003), “Advantages and Disadvantages of Senior-Care Organizations' Use of Foreign Employees," Community Development Journal, 104, pp. 402-412. 
27. Lee, B. Z., “Senior Care-Organizations' Business Management in Taipei City,” Unpublished Master's thesis, National Yang-Ming University, Taipei, Taiwan, Republic of China, 1997.

28. Lee, K. C. (2007), "Future Senior-Care Business Opportunity," Paper read at Taiwan International Senior Lifestyle and Health Care Conference on June 3-4, Taipei, Taiwan, Republic of China.

29. Lee, K. E. (2002), "Residents' Perception of Food Service in Continuing Care Retirement Communities," Dissertation Abstracts International. (UMI No. 3059632).

30. Lee, H. Y. L. and D. Yoo (2000), "The Determinants of Perceived Service Quality and Its Relationship with Satisfaction," Journal of Services Marketing, 14(3), pp. 217-231.

31. Lee, M. C. (2004), "The Effect of Senior Care Organizations Policies: A Study Focusing on Taipei," China and Taiwan Social Study Conference, Shanghai, China.

32. Lee, J. C. (2003), "Future Senior Care Product and Service," Paper read at the $15^{\text {th }}$ Shih Chien University Business School on Business Practical Conference, Taipei, Taiwan, Republic of China.

33. Liao, H. W. (2007), "Coming of Age Year" [Electronic version], Pollster Internet Research, 70. Retrieved September 9, 2007, from http://www.pollster.com.tw/report/70/index.htm.

34. Lipton, M. (2005), "Urban bias", in Forsyth, T. (ed) Encyclopedia of International Development, London: Routledge.

35. Mahoney, J. (1999), “Computer Companies Target Oldest, Wealthiest Market,” Austin American Statesman, Monday, May 31, D1.

36. Mertler, C. A. and R. A. Vannatta (2005), "Advanced and Multivariate Statistical Methods: Practical Application and Interpretation". Los Angeles: Pyrczak Publishing.

37. Ministry of Interior Taiwan Department of Social Affairs (2007), "Senior Welfare and Political," Retrieved March 23, 2007 from http://sowf.moi.gov.tw/04/01.htm.

38. Ministry of Interior Taiwan Department of Statistics, (2008), "Senior Long-Term Care, Senior-Care Organizations, and Retirement Home Statistics," Retrieved Week 10, 2008, from http://www.moi.gov.tw/stat/.

39. Ministry of Interior Taiwan Department of Statistics (1998), "Senior Care Welfare Organizations Statistics," Retrieved from http://sowf.moi.gov.tw/stat/Survey/survey11.doc.

40. Nwankwo, C. (2007), "Acceptance of Technology, Quality, and Customer Satisfaction with Information Technology Department in a Community College: A Case Study,” Dissertation Abstracts International, 230. (UMI No. 3285937).

41. Parasuraman, A., V. A. Zeithaml and L. L. Berry (1985), “A Conceptual Model of Service Quality and Its Implications for Future Research,” Journal of Marketing, 49, pp. 41-50.

42. Ramsaran-Fowdar, R. R. (2006), "Developing a Service Quality Questionnaire for the Hotel Industry in Mauritius," Journal of Vacation Marketing, 13, pp. 19-28.

43. Shi, C. Y. (1994), "The Decision Making Factors for the Seniors to Choose a Senior- Care Organization," The Economic and Social Council Journal, 14, pp. 101-125.

44. Skeese, M. E. (2002), “A Strategic Analysis of United Parcel Service,” Journal of Applied Management and Entrepreneurship, 7(4), pp. 108-126.

45. Stamps, P. L. (1997) "Nurses and Work Satisfaction: An Index for Measurement (2nd ed.)". Chicago: Health Administration Press.

46. Tabachnick, B. G. and L. S. Fidell (1996), “Using Multivariate Statistics ( $3^{\text {rd }}$ ed.)”. New York: HarperCollins.

47. Tsai, J. F. (2004), "What Is Rural Area?” East Sea Journal, 197, pp. 51-56.

48. Tsai, H. C. (1996). "A Study of Industrial Differentiation and Types among Rural Communities in Taiwan," Community Development Journal, 75, 135-143.

49. Tsai, H. Y. (2005), “The Job of Protecting the Seniors," Community Development Journal, 108, pp. 185-197.

50. Vuori, S. and M. Holmlund-Rytkonen (2005), "55+ People as Internet Users," Marketing Intelligence and Planning, 23(1), pp. 58-76.

51. Yang, P. S., G. U. Wang and M. T. Chiang (2005), "Experience and Analysis on Developing the Small Senior-Care Organizations Services," Community Development Journal, 110, pp. 321-339. 
52. Zeithaml, V. A., L. L. Berry and A. Parasuraman (1996), "The Behavioral Consequences of Service Quality," Journal of Marketing, 60, pp. 31-46.

\section{NOTES}

